\title{
$\begin{array}{lllllllll}\text { I } & \mathrm{N} & \mathrm{S} & \mathrm{T} & \mathrm{I} & \mathrm{T} & \mathrm{U} & \mathrm{T} & \mathrm{E}\end{array}$
}

\section{Paid Sick Time Helps Workers Balance Work and Family}

KRISTIN SMITH

$\mathrm{W}$ orking families across New Hampshire are nervously watching the flu season, hoping they or a family member will be spared this year. For the 26 percent of New Hampshire workers (excluding the self-employed) who do not have paid sick days, however, a sick child or a bout with the flu forces a difficult decision: stay home and lose wages or possibly even your job, or go to work sick or send your sick child to day care or school and put the health of others at risk. This choice is particularly salient during these times of record high unemployment and job layoffs. ${ }^{1}$ No one wants to risk appearing less devoted or committed to their job. Workers are all too aware of the instability in the job market, the potential for their employer to be the next casualty in this economic recession, and the long queue of the ready-to-work unemployed.

Some workers, particularly those in professional or managerial jobs, take their paid sick days for granted. Yet nationally, one-third of American workers have no paid sick days for themselves, and even fewer can take paid time to care for a sick child or family member. ${ }^{2}$ In New Hampshire, workers fare better than workers nationally, yet one-quarter of Granite State workers do not have paid sick days. ${ }^{3}$ Among New Hampshire workers with paid sick days, 22 percent can use it only to care for themselves and not for a family member.

Paid sick time is gaining legislative traction locally as well as federally. States are leading the way in considering legislation. Currently, thirteen states-five of which are in New England-have paid sick day legislation under consideration. ${ }^{4}$ Three municipalities have recently passed such legislation. ${ }^{5}$ On the federal level, in 2007 Congress introduced the Healthy Families Act, which would require employers with fifteen or more employees to provide their full-time workers with up to seven paid days per year, with a prorated amount for part-time workers. The Obama administration has signaled support for a federal sick day mandate as part of an ambitious work-family agenda. ${ }^{6}$
The New Hampshire legislature took up HB 662 in 2009, a bill that would require employers with ten or more employees to provide up to five sick days, and that includes a provision for part-time workers on a prorated basis. ${ }^{7}$ The committee has retained this bill for further discussion. National research shows that on average employees miss 1.6 days annually due to illness. ${ }^{8}$ For the New Hampshire businesses that do not offer paid sick days to their employees, this legislation may represent a short-term cost. However, the long-term benefits to employers who offer paid sick days include reduced contagion among coworkers, increased productivity, and reduced turnover. Many workers do not take unpaid time off when they are sick to avoid loss of income, because they fear losing their job, or to complete pressing work. ${ }^{9}$ New Hampshire's economy depends on the overall health of its workforce.

Figure 1. Percent of NH WORKers Lacking Paid Sick DAYS BY EDUCATION

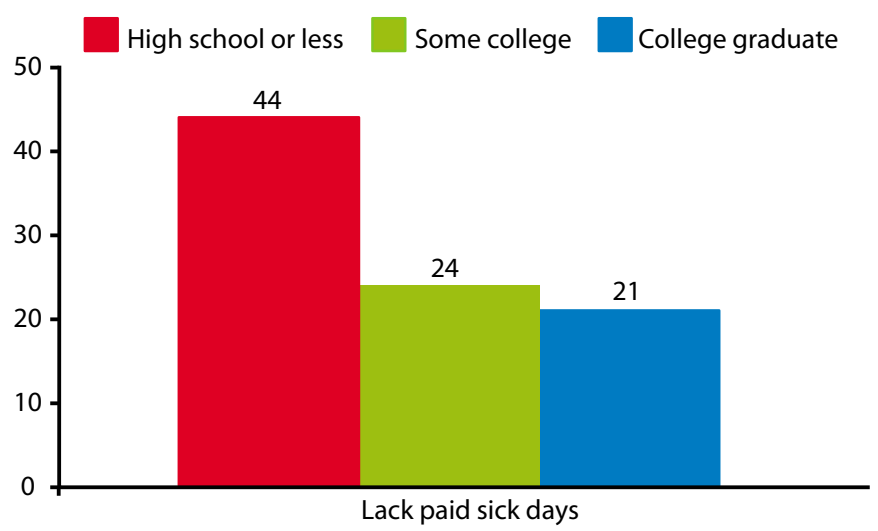

Source: Granite State Poll, Spring 2008 


\section{Who lacks paid sick time in New Hampshire?}

The biggest predictor of whether workers have paid sick days is whether they work full- or part-time hours: 65 percent of part-time workers lack paid sick time, but even 16 percent of full-time workers do not have this workforce standard. The lack of paid sick days among part-time workers is not surprising since many workplace benefits, such as health and dental insurance, are tied to full-time employment. However, other workplace standards are guaranteed for all workers, full-time and part-time alike, such as the minimum wage and safety codes.

Workers who can ill-afford to forgo a day's pay are often the least likely to have paid sick days. Low-income workers are less likely to have paid sick time than high-income workers. For example, 38 percent of the New Hampshire workforce earning less than $\$ 30,000$ annually lacks paid sick days compared with 15 percent of the workforce earning more than $\$ 100,000$ annually. Similarly, lower-educated workers are more likely to lack paid sick days than higher-educated workers (see Figure 1). When confronting the dilemma of caring for a sick child, two-thirds of low-income working families have left a sick child home alone or have lost pay to care for a child, ${ }^{10}$ illustrating the real toll that the lack of paid sick days takes on low-income families.

More families today rely on the wages of women to make ends meet. ${ }^{11}$ In 2007, 82 percent of women and 79 percent of mothers in New Hampshire were employed. Yet one-third of women workers in the state lack paid sick time, potentially compromising the health and economic well-being of families. Given that women shoulder substantial caregiving responsibilities for their children, elderly relatives, and persons with disabilities, the lack of paid sick time forces some women to choose between caring for a sick family member and contributing to their families' economic well-being. Furthermore, 48 percent of the New Hampshire workforce are women. Women contribute substantially to the New Hampshire economy, and paid sick days make it possible for women to work.

The business sector is the largest employer type in New Hampshire; more than one-half of all workers are employed by a business-sector firm. Employees in the business sector are less likely to have paid sick days than government employees (24 percent compared with 17 percent). ${ }^{12}$ Providing paid sick days may be costly to employers in the short term, but in the long term, paid sick days save employers money by reducing turnover and increasing productivity. ${ }^{13}$

\section{Balancing work and family: Paid sick days help}

The majority of New Hampshire workers say they are very or extremely successful at balancing work and family responsibilities (see Figure 2). Having paid sick time contributes to this sense of balance. Among full-time workers, those with paid sick days are more likely to say they feel very or extremely successful at balancing work and family than those without paid sick days (50 percent and 44 percent, respectively). Figure 3 also shows that women and business-sector workers working full-time who have paid sick days are also more likely to feel very or extremely successful at balancing work and family than their counterparts without paid sick days.

\section{Conclusion}

Everyone gets sick. Access to paid sick days is, therefore, a universal workforce issue. Paid sick time also cuts across the workforce: not all full-time or higher-wage workers have paid sick days. Even so, the lack of paid sick time disproportionately affects certain New Hampshire workers: part-time workers, low-wage workers, female workers, and businesssector workers. The lack of paid sick days places workers in a bind. They are forced to choose between caring for a sick family member or themselves and losing pay. Two-thirds of

FIgURE 2. SUCCESS AT BALANCING WORK AND FAMILY, NH WORKERS

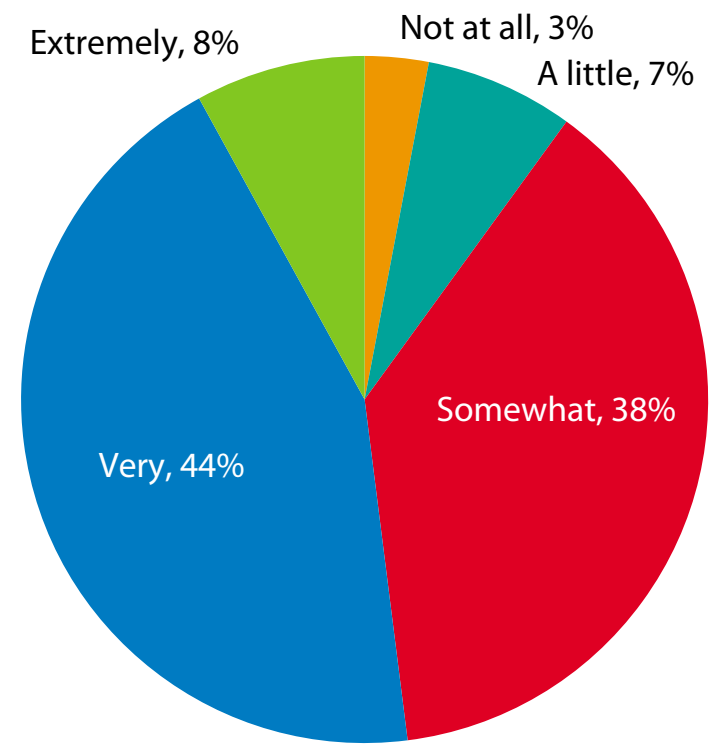

Source: Granite State Poll, Spring 2008 
Figure 3. Percent feEling Very SUCCESSFUL AT BALANCING WORK AND FAMILY BY ACCESS TO PAID SICK DAYS, NH FULL-TIME WORKERS

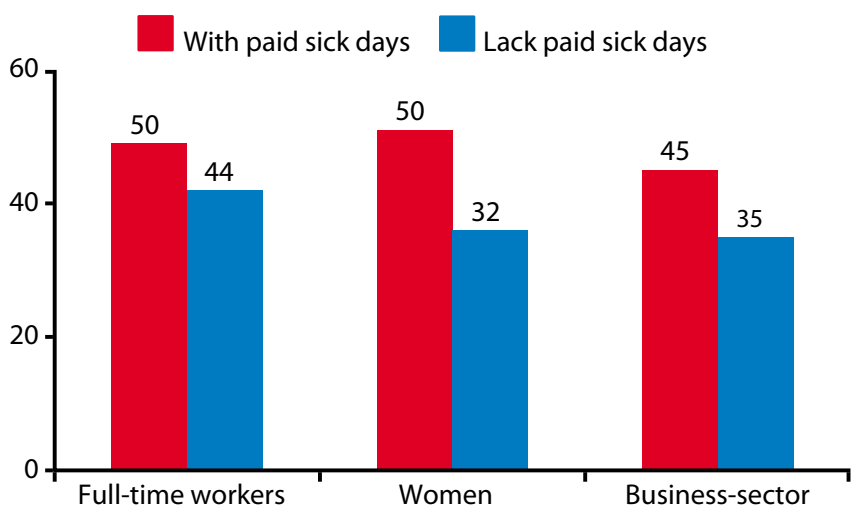

Source: Granite State Poll, Spring 2008

workers nationally do not take unpaid sick time when they need it because of the loss of income. ${ }^{14}$ Many workers feel that taking unpaid sick time puts their job in jeopardy, ${ }^{15}$ something that no worker wants to do in today's tight labor market.

A healthy workforce is key to a vibrant, productive economy. Evidence from San Francisco shows that paid sick days do not hurt job growth or the economy of a city; rather, they provide job protection to workers and a steady paycheck when they need to care for themselves or their family. ${ }^{16}$ In these difficult economic times, working families should not be forced to choose between this rock and a hard place.

\section{Data Used}

This fact sheet uses data on paid sick time and work and family balance from the New Hampshire Granite State Poll collected in the spring of 2008 (sample size of $288 \mathrm{New}$ Hampshire workers) and data on the New Hampshire workforce from the 2007 American Community Survey (ACS) (sample size of 7,202 New Hampshire workers). Estimates from the Granite State Poll have a 4 percentage point confidence interval (plus or minus).

\section{A U THOR}

Kristin Smith is a family demographer at the Carsey Institute and Research Assistant Professor of Sociology at the University of New Hampshire. Contact her at kristin.smith@unh.edu.

\section{A C K N OW L E D G EM EN T S}

The author thanks Rebecca Glauber at the University of New Hampshire; Mil Duncan, Anne Shattuck, Mica Stark, and Amy Sterndale at the Carsey Institute; and Barbara Ray for their thoughtful comments and suggestions.

\section{E N D N O T E S}

${ }^{1}$ Bureau of Labor Statistics, "Economic News Release: Employment Situation Summary" (Washington, DC: BLS, 2009), accessed January 2009 at http://www.bls.gov/news. release/empsit.nr0.htm.

${ }^{2}$ Tom Smith, "Paid Sick Days: A Basic Labor Standard for the 21st Century" (Washington, DC: National Opinion Research Center at the University of Chicago and Public Welfare Foundation, 2008).

${ }^{3}$ The research on paid sick days in New Hampshire presented in this fact sheet is based on questions placed on the Granite State Poll in the spring of 2008. Access to paid sick days may be higher in New Hampshire than in the nation as a whole if New Hampshire workers have higher than average work-related benefits. This may be the case because of the prevalence of jobs in the high-end service sector, the relatively highly educated, skilled, and older New Hampshire workforce, and the low prevalence of poverty in the Granite State. However, it is also possible that the small sample size and the over representation of highly educated and public-sector workers in the Granite State Poll yields a slightly higher estimate.

${ }^{4}$ The thirteen states include California, Connecticut, Illinois, Maine, Maryland, Massachusetts, Minnesota, Montana, New Hampshire, North Carolina, Oregon, Pennsylvania, and Vermont.

${ }^{5}$ Paid sick days legislation passed in San Francisco in 2006 and in Washington, DC, and Milwaukee in 2008.

${ }^{6}$ Sue Shellenbarger, "Family Time: Lawmakers Push to Expand Paid Leave," Wall Street Journal, Work and Family Section, November 19, 2008.

${ }^{7}$ In 2008, 15 percent of New Hampshire firms had ten or more employees, representing roughly 85 percent of New Hampshire employment in the business sector. For more information, see the website for the Economic and Labor Market Information Bureau of NH Employment Security: http://www.nh.gov/nhes/elmi/pdfzip/econstat/covempwag/ FBS/fbs_State_nh0801.xls. 
${ }^{8}$ This excludes leave for maternity. Workers with paid sick time miss an average of 1.8 days and those without miss an average of 1.3 days annually. See Vicky Lovell, "Valuing Good Health in Massachusetts: An Estimate of Costs and Savings for Paid Sick Days Act" (Washington, DC: Institute for Women's Policy Research, 2005).

${ }^{9}$ Vicky Lovell, "No Time to Be Sick: Why Everyone Suffers When Workers Don't Have Paid Sick Leave" (Washington, DC: Institute for Women's Policy Research, 2004).

${ }^{10}$ Jody Heymann, Forgotten Families: Ending the Growing Crisis Confronting Children and Working Parents in the Global Economy (New York: Oxford University Press, 2006).

${ }^{11}$ Kristin Smith, "Working Hard for the Money: Trends in Women's Employment, 1970-2007," Report on Rural America no. 5 (Durham, NH: Carsey Institute, University of New Hampshire, 2009).
${ }^{12}$ Thirteen percent of New Hampshire workers were selfemployed, employed by another employer type, or did not answer the employer type question. Among this group, 57 percent lack paid sick days.

${ }^{13}$ Boushey, Heather, Layla Monghari, Sara Sattelmeyer, and Margy Waller, "Work-Life Policies for the Twenty-First Century Economy" (Washington, DC: The Mobility Agenda, 2008); Lovell, "No Time to be Sick."

${ }^{14}$ Naomi Gerstel and Katherine McGonagle, "Job Leaves and the Limits of the Family and Medical Leave Act: The Effects of Gender, Race, and Family," Work and Occupations 26(4)(1999): 510-534.

${ }^{15}$ Smith, "Paid Sick Days."

${ }^{16}$ See the National Partnership for Women website: http://www.nationalpartnership.org/site/ PageServer?pagename=psd_index.

\section{CARSEY}

Building knowledge for families and communities

The Carsey Institute conducts policy research on vulnerable children, youth, and families and sustainable community development. We give policymakers and practitioners timely, independent resources to effect change in their communities.

Huddleston Hall

73 Main Street

Durham, NH 03824

(603) 862-2821

\section{www.carseyinstitute.unh.edu}

This work was supported by the Public Welfare Foundation and the Carsey endowment. 